\title{
FORMATION OF SEED PRODUCTIVITY AND SOWING QUALITIES OF RED CLOVER SEED DEPENDING ON THE EFFECT OF LIME, MINERAL AND WATER-SOLUBLE FERTILIZERS
}

\author{
S.F. Antoniv, S.I. Kolisnyk, O.A. Zapruta
}

Institute of Feed Research and Agriculture of Podillia, NAAS

16, Yunosti prosp., Vinnytsia, Ukraine, 21100

E-mail:inkor_nas@i.ua; kolesniksi@ukr.net; alexik27@gmail.com

Received on July 23, 2018 / Received August 22, 2018 / Accepted November 21, 2018

\begin{abstract}
Aim. Development of efficient fertilization of red clover seed sowings with mineral, lime and microfertilizers in order to optimize plant nutrition during their vegetation period to obtain stable seed yields with high sowing and yield qualities. Methods. field, visual, measuring, weight, quantitative, method of a test sheaf, laboratory, mathematical-statistical. Results. The paper presents the results of optimizing the nutrition of red clover seed sowings on the basis of the rational application of quick-acting lime $\left(\mathrm{Ca}(\mathrm{OH})_{2}-0.5\right.$ of the rate by hydrolytic acidity, mineral $\left(\mathrm{N}_{30} \mathrm{P}_{60} \mathrm{~K}_{60}\right)$ and water-soluble fertilizers, which ensured seed yield increase 1.8-2.0 times at the level of 0.35-0.40 t/ha. Conclusions. The most effective combination of the basic fertilization with mineral fertilizers $\left(\mathrm{N}_{30} \mathrm{P}_{60} \mathrm{~K}_{60}\right)$ and lime fertilizers $\left(\mathrm{Ca}(\mathrm{OH})_{2}\right)$ at the rate of 0.5 by hydrolytic acidity applied under the cover crop using water-soluble fertilizer (plantafol $-1.0 \mathrm{~kg} / \mathrm{ha})$ and boric fertilizers $\left(\mathrm{H}_{3} \mathrm{BO}_{4}-0.8 \mathrm{~kg} / \mathrm{ha}\right)$ at the shooting stage of the second cut of red clover and molybdenum fertilizers $\left(\left(\mathrm{CNH}_{4}\right)_{2} \mathrm{MoO}_{4}-0.3 \mathrm{~kg} / \mathrm{ha}\right) \mathrm{in}$ spring at the beginning of its regrowth.
\end{abstract}

Keywords: red clover, seed sowings, yield, lime, mineral and water-soluble fertilizers.

DOI: https://doi.org/10.15407/agrisp5.03.027

\section{INTRODUCTION}

The intensification of field and meadow feed production envisages the use of perennial grasses, which ensure high yield of green mass and high-quality hay. These requirements are met by red clover, which, along with alfalfa, is the most common forage crop, solving the problems of producing vegetative protein and increasing the fertility of soils. Here red clover is one of the most reliable and high-yield crops, especially by the amount of obtained forage protein [1, 2, 3, 4].

In the Forest-Steppe of Ukraine red clover takes about $50 \%$, and in Polissia $-15-20 \%$ of the area of legume grass sowings. While growing the latter for seeds, a considerable amount of nutrients is removed from soil: at the yield of seeds of $0.35 \mathrm{t} / \mathrm{ha}$ and straw $4.5 \mathrm{t} / \mathrm{ha}$, the total removal of nitrogen $(\mathrm{N})$ is 60 , phosphorus $\left(\mathrm{P}_{2} \mathrm{O}_{5}\right)-55$, potassium $\left(\mathrm{K}_{2} \mathrm{O}\right)-94$, calcium $(\mathrm{CaO})-89 \mathrm{~kg} / \mathrm{ha}[5,6]$, thus the fertilization for seed sowings of this crop, in particular, the application of

(C) S.F. ANTONIV, S.I. KOLISNYK, O.A. ZAPRUTA, 2018 new forms of micro- and water-soluble fertilizers and quick-acting calcium-containing fertilizers impacts the seed productivity of red clover considerably.

\section{MATERIALS AND METHODS}

The experiments were conducted in the experimental farm "Bohonytske" of the Institute of Feed Research and Agriculture of Podillia, NAAS, in the crop rotation of the department of seed development and innovation transfer in 2011-2013. Gray forest soil was used with the following indices: $\mathrm{pH}-4.8-5.2$, hydrolytic acidity $-2.73-3.04 \mathrm{mg}$-eq. per $100 \mathrm{~g}$ of soil, the sum of absorbed alkali $12-13 \mathrm{mg}$-eq. per $100 \mathrm{~g}$ of soil, in the arable layer of soil $(0-20 \mathrm{~cm})$ the content of humus was $1.91-2.40 \%$, easily hydrolyzed nitrogen $(\mathrm{N})$ by Kornfeld 7.5-10.0, mobile forms of phosphorus $\left(\mathrm{P}_{2} \mathrm{O}_{5}\right)$ by Chirikov and potassium $\left(\mathrm{K}_{2} \mathrm{O}\right)$ respectively $15-19$, $10.3-12.5 \mathrm{mg}$ per $100 \mathrm{~g}$ of soil.

The cover crop, protecting the sowing of red clover from weeds, winds, cold, and heat, was spring barley, Lofant variety, with the norm of sowing of 3 million 
seeds for germination per 1 ha. The norm of sowing red clover, Sparta variety, is 7 million seeds for germination per 1 ha of certified seeds. The area of the registered area was 25 sq.m., the number of repeats 3 times.

Phosphorus-potassium fertilizers in the form of granulated superphosphate and potassium chloride and lime fertilizers in the form of $\mathrm{CaCO}_{3}$ (defecate) and slaked lime - hydrated lime $\left(\mathrm{Ca}(\mathrm{OH})_{2}\right)$ on grey forest soils were introduced in autumn under the main tillage of soil according to the scheme of studies. Nitrogen fertilizers (ammonium nitrate) were introduced in spring under the cover crop.

Water-soluble fertilizer - plantafol - was introduced according to the scheme of experiment in the phase of shooting $(1 \mathrm{~kg} / \mathrm{ha})$ and in the bud phase of red clover $(1 \mathrm{~kg} / \mathrm{ha})$. By its composition plantafol contained $\mathrm{N}-$ $5 \%, \mathrm{P}_{2} \mathrm{O}_{5}-15 \%, \mathrm{~K}_{2} \mathrm{O}-45 \%, \mathrm{~B}-0.02 \%, \mathrm{Fe}-$ $0.01 \%, \mathrm{Mn}-0.05 \%, \mathrm{Zn}-0.05 \%, \mathrm{Cu}-0.05 \%$. Here copper, iron, magnesium, zinc in plantafol were chelates in the EDTA form (ethylenediaminotetraacetic acid). In addition, the experiments used molybdenum fertilizers $\left(\left(\mathrm{CNH}_{4}\right)_{2} \mathrm{MoO}_{4}-\right.$ acid ammonium molybdate) $-0.3 \mathrm{~kg} / \mathrm{ha}$ in spring at the beginning of regrowth of red clover and borium $\left(\mathrm{H}_{3} \mathrm{BO}_{4}\right.$ - boric acid) $0.8 \mathrm{~kg} / \mathrm{ha}$ at the shooting stage of the second cut of red clover for seeds. Except for variants under study in the experiment, agroequipment was common for these zonal conditions.

A structural analysis of yield was conducted prior to harvesting by determining the number of generative shoots and ripe heads per 1 sq.m. in six places of each variant. The mass of seeds in grams and their number were defined in 30 randomly selected heads of red clover. The number of seeds was calculated in 10 heads. In addition, the experiment determined the mass of 1,000 seeds, energy and germination of seeds, percentage of pollinated flowers in one head.

\section{RESULTS OF INVESTIGATIONS}

A relevant agrotechnical technique in farming seeds of red clover is liming acid soils. A high content of seeds may be obtained only on neutral and slightly acid soil. Red clover plants are most sensitive to acid reaction of soil at the initial stages of development during the sowing year. Acid soils have aluminum and magnesium in the amount of over $3 \mathrm{mg}$ per $100 \mathrm{~g}$ of soil, which have a toxic effect on young shoots of plants. Their action is decreased by liming. Acid medium inhibits the activity of nodule bacteria, plants are poorly developed due to the disruption of nitrogen exchange in them. The introduction of lime fertilizers even prior to sowing red clover increased its seed productivity considerably $[5,6,7]$. Increased acidity of soil inhibits the improvement of seed performance, limits a positive action of other elements of cultivation technology. Liming acid soils improves the supply of phosphorus for plants, enhances winter-resistance, promotes better growth of vegetative organs, blossoming occurs better and with higher amount of viable pollen, which conditions the growth in seed yield $[8,9]$.

Liming can decrease acidity from $\mathrm{pH} 5.0$ to $6.2-6.5$ and thus increase the yield of red clover, though here the latter is also sensitive to over-liming and high content of salts [10].

According to the results of the studies red clover develops optimally at $\mathrm{pH}$ 6.0-6.5, accumulating about $300 \mathrm{~kg} / \mathrm{ha}$ of nitrogen in soil, and forms the yield of seeds up to $0.5-0.6 \mathrm{t} / \mathrm{ha}$ in case of following the requirements of other technological operations. At $\mathrm{pH}$ 4.0-5.0 this crop can grow and develop, but it accumulates only $80-100 \mathrm{~kg} / \mathrm{ha}$ of nitrogen and forms the yield of seeds of $0.15-0.20 \mathrm{t} / \mathrm{ha}$ [5].

The results of studies, conducted in 2011-2013, demonstrated that the introduction of lime fertilizers in the form of $\mathrm{CaCO}_{3}$ (defecate) and $\mathrm{Ca}(\mathrm{OH})_{2}$ (slacked lime - hydrated lime) -0.5 of the rate by hydrolytic acidity prior to ploughing under the cover crop had a considerable impact on the yield of seeds of red clover, Sparta variety (Table).

The yield of red clover seeds on the plots, where liming was conducted using quickly-acting soluble lime fertilizers in the form of $\mathrm{Ca}(\mathrm{OH})_{2}$ in combination with the application of mineral fertilizers in the dose of $\mathrm{N}_{30} \mathrm{P}_{60} \mathrm{~K}_{60}$ under the cover crop (factor $\mathrm{A}$ ) on average for 2011-2013 was $291 \mathrm{~kg} / \mathrm{ha}$, which was $115 \mathrm{~kg} / \mathrm{ha}$ more compared to the variant, where neither mineral nor lime fertilizers were introduced (control) and 63 $\mathrm{kg} / \mathrm{h}$ a more compared to the plots with the introduction of mineral fertilizers only. After the introduction of calcium fertilizers in the form of $\mathrm{CaCO}_{3}$ in combination with the application of mineral fertilizers in the dose of $\mathrm{N}_{30} \mathrm{P}_{60} \mathrm{~K}_{60}$ (factor A) this index was considerably lower and amounted to $266 ; 90 ; 38 \mathrm{~kg} /$ ha respectively. It demonstrated high efficiency of quickly-acting lime fertilizers in the form of slacked lime $\left(\mathrm{Ca}(\mathrm{OH})_{2}\right)$ during the first year after their application.

To obtain high stable yields of red clover seeds, the plants should be provided both with macro- and mi- 


\section{FORMATION OF SEED PRODUCTIVITY AND SOWING QUALITIES OF RED CLOVER SEED DEPENDING}

The yield of red clover seeds depending on the action of lime, mineral and water-soluble fertilizers, $\mathrm{kg} / \mathrm{ha}$

\begin{tabular}{|c|c|c|c|c|}
\hline \multirow{2}{*}{ Foliar application, Factor B } & \multicolumn{3}{|c|}{ Years } & \multirow{2}{*}{ Average } \\
\hline & 2011 & 2012 & 2013 & \\
\hline \multicolumn{5}{|c|}{ No fertilizers-control } \\
\hline No additional nutrition & 245 & 115 & 167 & 176 \\
\hline Plantafol $-1 \mathrm{~kg} / \mathrm{ha}$ at the shooting stage & 258 & 131 & 189 & 193 \\
\hline Variant $2+$ Mo at the beginning of regrowth & 280 & 135 & 194 & 203 \\
\hline Variant $2+B$ at the shooting stage & 297 & 141 & 201 & 213 \\
\hline Variant $2+\mathrm{Mo}+\mathrm{B}$ & 322 & 147 & 209 & 226 \\
\hline Plantafol $-1 \mathrm{~kg} / \mathrm{ha}$ at the bud stage & 297 & 137 & 197 & 210 \\
\hline Variant $2+$ variant 6 & 313 & 139 & 201 & 218 \\
\hline Average & 287 & 135 & 194 & 205 \\
\hline \multicolumn{5}{|c|}{$N_{30} P_{60} K_{60}$} \\
\hline No additional nutrition & 288 & 179 & 217 & 228 \\
\hline Plantafol $-1 \mathrm{~kg} / \mathrm{ha}$ at the shooting stage & 307 & 198 & 241 & 249 \\
\hline Variant $9+$ Mo at the beginning of regrowth & 315 & 201 & 267 & 261 \\
\hline Variant $9+\mathrm{B}$ at the shooting stage & 323 & 203 & 278 & 268 \\
\hline Variant $9+\mathrm{Mo}+\mathrm{B}$ & 349 & 207 & 301 & 286 \\
\hline Plantafol $-1 \mathrm{~kg} / \mathrm{ha}$ at the bud stage & 321 & 201 & 263 & 262 \\
\hline Variant $9+$ variant 13 & 324 & 203 & 270 & 266 \\
\hline Average & 318 & 199 & 262 & 260 \\
\hline \multicolumn{5}{|c|}{$\mathrm{Ca}(\mathrm{OH})_{2}+\mathrm{N}_{30} \mathrm{P}_{60} \mathrm{~K}_{60}$} \\
\hline No additional nutrition & 346 & 215 & 312 & 291 \\
\hline Plantafol $-1 \mathrm{~kg} / \mathrm{ha}$ at the shooting stage & 356 & 225 & 341 & 307 \\
\hline Variant $16+$ Mo at the beginning of regrowth & 357 & 234 & 358 & 283 \\
\hline Variant $16+\mathrm{B}$ at the shooting stage & 385 & 241 & 369 & 332 \\
\hline Variant $16+\mathrm{Mo}+\mathrm{B}$ & 399 & 254 & 401 & 351 \\
\hline Plantafol $-1 \mathrm{~kg} / \mathrm{ha}$ at the bud stage & 376 & 230 & 360 & 322 \\
\hline Variant $16+$ variant 20 & 380 & 233 & 368 & 327 \\
\hline Average & 371 & 233 & 344 & 316 \\
\hline \multicolumn{5}{|c|}{$\mathrm{CaCO}_{3}+\mathrm{N}_{30} \mathrm{P}_{60} \mathrm{~K}_{60}$} \\
\hline No additional nutrition & 304 & 209 & 286 & 266 \\
\hline Plantafol $-1 \mathrm{~kg} / \mathrm{ha}$ at the shooting stage & 322 & 218 & 309 & 283 \\
\hline Variant $23+$ Mo at the beginning of regrowth & 336 & 224 & 322 & 294 \\
\hline Variant $23+\mathrm{B}$ at the shooting stage & 359 & 226 & 333 & 306 \\
\hline Variant $23+\mathrm{Mo}+\mathrm{B}$ & 373 & 232 & 356 & 320 \\
\hline Plantafol $-1 \mathrm{~kg} / \mathrm{ha}$ at the bud stage & 352 & 220 & 317 & 296 \\
\hline Variant $23+$ variant 27 & 359 & 224 & 325 & 303 \\
\hline Average & 344 & 222 & 321 & 296 \\
\hline \multicolumn{5}{|l|}{$\mathrm{HIP}_{05}$} \\
\hline $\mathrm{A}$ & 8.4 & 8.1 & 6.9 & \\
\hline $\mathrm{B}$ & 11.1 & 10.7 & 9.1 & \\
\hline $\mathrm{AB}$ & 7.3 & 7.0 & 6.0 & \\
\hline
\end{tabular}


croelements: borium, molybdenum, magnesium, zinc, cobalt, iron, sulfur. Microfertilizers promote intense accumulation of organic substances, increase in winterresistance of plants and resistance to diseases, increase growth and accelerate development, improve the quality of products [6]. Thus, on the second year of life for red clover the scheme of studies should include foliar application of water-soluble fertilizers (plantafol - 1 $\mathrm{kg} / \mathrm{ha}$ ) and borium and molybdenum fertilizers (factor B).

When water-soluble fertilizers are introduced, plants receive nutrients via leaves. When introduced onto the plant, they are capable of causing considerable changes in the growth and development of plants. Water-soluble fertilizers get involved into the metabolism of substances, increase the level of vital activity, save water for plants, and activate microbiological processes. It is efficient to use water-soluble fertilizers with microfertilizers.

For instance, borium (B) enhances the intensity of photosynthesis, regulates pollination and settlement, improves carbohydrate and protein exchange, activates the activity of enzymes, has positive impact on the processes of cell division, enhances resistance to diseases. Also, borium improves synthesis and transfer of carbohydrates, especially sugars from the leaves to the organs of fruit-bearing and roots [6].

Molybdenum (Mo) is an irreplaceable component of many enzymes. It participates in carbohydrate, nitrogen, and phosphorus exchange, synthesis of vitamins and chlorophyll, increases the intensity of photosynthesis, is included to the composition of enzymes of nitroreductase, which takes part in the oxidation of nitrates to ammonium in plants. An important part is attributed to molybdenum in the processes of nitrogen fixation from the atmosphere by nodule and free bacteria [6].

The application of water-soluble fertilizers at the shooting stage $(1 \mathrm{~kg} / \mathrm{ha})$ ensured the yield of seeds of $193 \mathrm{~kg} / \mathrm{ha}$ on average during the years of studies (20112013) when they were introduced in the bud phase, the yield of red clover seeds was somewhat higher and amounted to $210 \mathrm{~kg} / \mathrm{ha}$ or $17 \mathrm{~kg} / \mathrm{ha}$ more compared to the introduction in the shooting phase and $34 \mathrm{~kg} / \mathrm{ha}$ more compared to the variant with no additional nutrition. The combination of additional introduction of microfertilizers (Mo, B) in the control (variant 5) promoted a considerable growth in the yield of seeds (on average by $50 \mathrm{~kg} / \mathrm{ha}$ in 2011-2013.) The introduction of plantafol at the shooting stage for red clover $(1 \mathrm{~kg} / \mathrm{ha})$ and its additional application in the bud phase (vari- ant 7) promoted the growth of seed performance. The combination of introduction in these phases compared to the application at the stage of shooting or in the bud phase was more efficient and promoted the increase in the yield of red clover by 25 and $8 \mathrm{~kg} /$ ha respectively.

The introduction of water-soluble fertilizers during red clover vegetation at the background of applying mineral fertilizers $\left(\mathrm{N}_{30} \mathrm{P}_{60} \mathrm{~K}_{60}\right)$ under the cover crop promoted further considerable growth in the seed performance of red clover. In particular, the application of plantafol $(1 \mathrm{~kg} / \mathrm{ha})$ at the shooting stage at the background of $\mathrm{N}_{30} \mathrm{P}_{60} \mathrm{~K}_{60}$ increased the yield of seeds by $21 \mathrm{~kg} / \mathrm{ha}$. The application of molybdenum and borium fertilizers and their combination at this background promoted the increase in this index by $12,19,58 \mathrm{~kg} /$ ha respectively. The introduction of plantafol $(1 \mathrm{~kg} / \mathrm{ha})$ in the bud phase ensured the yield of red clover seeds at the level of $262 \mathrm{~kg} / \mathrm{ha}$ (variant 13), which was 12 $\mathrm{kg} / \mathrm{ha}$ more compared to its application at the shooting stage at the background of $\mathrm{N}_{30} \mathrm{P}_{60} \mathrm{~K}_{60}$ (variant 9). The combination of the introduction of water-soluble fertilizers at the shooting stage and in the bud phase at the background of mineral fertilizer did not promote a considerable growth of its seed performance (variant 14).

The application of water-soluble fertilizers at the background of introduction of mineral fertilizers $\left(\mathrm{N}_{30} \mathrm{P}_{60} \mathrm{~K}_{60}\right)$ and liming with quickly-acting lime fertilizers $\left(\mathrm{Ca}(\mathrm{OH})_{2}\right)$ promoted further considerable growth of the yield of red clover seeds. In particular, the introduction of Plantafol in the dose of $1 \mathrm{~kg} / \mathrm{ha}$ at the shooting stage at the abovementioned background (variant 16) ensured the yield of red clover seeds at the level of $307 \mathrm{~kg} / \mathrm{ha}$ on average during 2011-2013. At this background the introduction of additional molybdenum $(0.3 \mathrm{~kg} / \mathrm{ha})$ and borium $(0.8 \mathrm{~kg} / \mathrm{ha})$ fertilizers and their combination promoted the formation of the yield of seeds respectively $316 ; 332 ; 351 \mathrm{~kg} / \mathrm{ha}$ (variants 17 , $18,19)$ or respectively by $16 ; 25 ; 41 ; 60 \mathrm{~kg} /$ ha more compared to the variant without introduction of watersoluble fertilizers (variant 15).

The application of water-soluble fertilizers in the bud phase of red clover at the background of liming using slacked lime and mineral fertilizer $\mathrm{N}_{30} \mathrm{P}_{60} \mathrm{~K}_{60}$ was efficient and ensured the formation of yield at the level of $322 \mathrm{~kg} / \mathrm{ha}$ on average in 2011-2013 (variant 20), which was $15 \mathrm{~kg} / \mathrm{ha}$ more compared to the application of plantafol at the shooting stage (variant 16).

Water-soluble fertilizers and microfertilizers, introduced at the background of mineral fertilizers and liming using calcium fertilizers in the form of $\mathrm{CaCO}_{3}$ 


\section{FORMATION OF SEED PRODUCTIVITY AND SOWING QUALITIES OF RED CLOVER SEED DEPENDING}

which are hard for plants to get during the first years after the introduction or which are less efficient (variants 23-28) and ensured the formation of the yield of seeds in the investigated variants $283-320 \mathrm{~kg} / \mathrm{ha}$, which was $17-54 \mathrm{~kg} / \mathrm{ha}$ more compared to the variant without additional nutrition (variant 22) and 8-10\% less compared to the variants, where quickly-acting lime fertilizers were introduced (variants 15-21).

A similar phenomenon was observed in terms of seed quality. The highest germination of seeds (on average by variants) (94-95\%) was obtained in the variants with liming, whereas in the plots without fertilizers it was $91-92 \%$ on average during the years of studies, while in the variant with the introduction of mineral fertilizers only it was $91-93 \%$. Liming also impacted the mass of 1,000 of seeds. The largest mass of 1,000 seeds $(1.73 \mathrm{~g})$ was noted in the variant with slacked lime in combination with mineral fertilizers $\left(\mathrm{N}_{30} \mathrm{P}_{60} \mathrm{~K}_{60}\right)$, while in the variant where the main fertilization using lime and mineral fertilizers was not conducted it was $1.60 \mathrm{~g}$.

Thus, the highest yield of red clover seeds $(351 \mathrm{~kg} / \mathrm{ha})$ on average in 2011-2013 was obtained in the variant with the introduction of quickly-acting lime fertilizers $\left(\mathrm{Ca}(\mathrm{OH})_{2}\right)-0.5$ of the rate by hydrolytic acidity and mineral fertilizers $\left(\mathrm{N}_{30} \mathrm{P}_{60} \mathrm{~K}_{60}\right)$ under the cover crop with the application of molybdenum fertilizers $(0.3 \mathrm{~kg} / \mathrm{ha})$ in spring at the regrowth of red clover in combination with the introduction of water-soluble (plantafol $1 \mathrm{~kg} / \mathrm{ha})$ and borium $(0.8 \mathrm{~kg} / \mathrm{ha})$ fertilizers at the shooting stage of the crop.

\section{CONCLUSIONS}

The introduction of quickly-acting lime fertilizers in the form of $\mathrm{Ca}(\mathrm{OH})_{2}$ (hydrated lime - slacked lime) on gray forest soil at 0.5 of rate by hydrolytic acidity prior to ploughing under the cover crop in combination with the application of mineral fertilizers in the dose of $\mathrm{N}_{30} \mathrm{P}_{60} \mathrm{~K}_{60}$ ensured the yield of red clover seeds in conditions of 2011-2013 at the level of $291 \mathrm{~kg} / \mathrm{ha}$, which was $115 \mathrm{~kg} / \mathrm{ha}$ more compared to the plots without fertilizers and $63 \mathrm{~kg} / \mathrm{ha}$ more compared to the plots, where only mineral fertilizers were introduced. At the introduction of calcium fertilizers in the form of $\mathrm{CaCO}_{3}$ (defecate) these indices were 9-12\% lower.

The application of mineral fertilizers $\left(\mathrm{N}_{30} \mathrm{P}_{60} \mathrm{~K}_{60}\right)$ under the cover crop of red clover promoted the increase in the yield of seeds by $52 \mathrm{~kg} / \mathrm{ha}$ or by $23 \%$ compared to the plots, which were not fertilized.

The most effective combination is uniting the basic fertilization with mineral fertilizers $\left(\mathrm{N}_{30} \mathrm{P}_{60} \mathrm{~K}_{60}\right)$ and lime fertilizers $\left(\mathrm{Ca}(\mathrm{OH})_{2}\right)$ at 0.5 of the rate by hydrolytic acidity applied under the cover crop using watersoluble fertilizer (plantafol $-1.0 \mathrm{~kg} / \mathrm{ha}$ ) and boric fertilizers $\left(\mathrm{H}_{3} \mathrm{BO}_{4}-0.8 \mathrm{~kg} / \mathrm{ha}\right)$ at the shooting stage of the second cut of red clover and molybdenum fertilizers $\left(\left(\mathrm{CNH}_{4}\right)_{2} \mathrm{MoO}_{4}-0.3 \mathrm{~kg} / \mathrm{ha}\right)$ in spring at the beginning of regrowth of red clover, which ensured the yield of seeds at the level of $351 \mathrm{~kg} / \mathrm{ha}$ or $50 \%$ more compared to the plots without fertilizers with high sowing qualities of seeds (germination of $94-95 \%$, mass of 1,000 seeds $-1.73 \mathrm{~g})$.

\section{Формування насіннєвої продуктивності та посівних якостей насіння конюшини лучної залежно від дії вапнякових, мінеральних та водорозчинних добрив \\ С. Ф. Антонів, С. І. Колісник, О. А. Запрута \\ Інститут кормів та сільського господарства Поділля HAAH \\ Проспект Юності, 16, Вінниця, Україна, 21100 \\ e-mail: inkor_nas@i.ua; kolesniksi@ukr.net; alexik27@gmail.com}

Мета. Розробка раціонального удобрення насіннєвих посівів конюшини лучної мінеральними, вапняковими та мікродобривами 3 метою оптимізації живлення рослин протягом їх вегетації 3 ціллю отримання стабільних урожаїв насіння з високими посівними та врожайними властивостями. Методи. Польовий, візуальний, вимірювальний, ваговий, кількісний, метод пробного снопа, лабораторний, математично-статистичний. Результати. Висвітлено результати оптимізації живлення насіннєвих посівів конюшини лучної на основі раціонального застосування швидкодіючих вапнякових $\left(\mathrm{Ca}(\mathrm{OH})_{2}-0,5\right.$ норми за гідролітичною кислотністю, мінеральних $\left(\mathrm{N}_{30} \mathrm{P}_{60} \mathrm{~K}_{60}\right)$ та водорозчинних добрив, що забезпечило підвищення врожаю насіння в 1,8-2,0 рази на рівні 0,35-0,40 т/га. Висновки. Найбільш ефективним $є$ поєднання основного удобрення мінеральними $\left(\mathrm{N}_{30} \mathrm{P}_{60} \mathrm{~K}_{60}\right)$ та вапняковими добривами $\left(\mathrm{Ca}(\mathrm{OH})_{2}\right)$ в 0,5 нормі за гідролітичною кислотністю, внесених під покривну культуру iз застосуванням молібденових добрив $\left(\left(\mathrm{CNH}_{4}\right)_{2} \mathrm{MoO}_{4}-\right.$ 0,3 кг/га) весною на початку відростання конюшини лучної водорозчинних (Плантафолу - 1,0 кг/га) і борних добрив $\left(\mathrm{H}_{3} \mathrm{BO}_{4}-0,8\right.$ кг/га) у фазу стеблування другого укосу.

Ключові слова: конюшина лучна, насіннєві посіви, урожай, вапнякові, мінеральні та водорозчинні добрива.

\section{Формирование семенной продуктивности \\ и посевных качеств семян клевера лугового в зависимости от действия известковых, минеральных и водорастворимых удобрений}

С. Ф. Антонив, С. И. Колесник, А. А. Запрута 
ANTONIV et al.

Институт кормов и сельского хозяйства Подолья НААН

Проспект Юности, 16, Винница, Украина, 21100

e-mail: inkor_nas@i.ua; kolesniksi@ukr.net; alexik27@gmail.com

Цель. Разработка рационального удобрения семенных посевов клевера лугового минеральными, известковыми и микроудобрениями с целью оптимизации питания растений в течение их вегетации с целью получения стабильных урожаев семян с высокими посевными и урожайными свойствами. Методы. Полевой, визуальный, измерительный, весовой, количественный, метод пробного снопа, лабораторный, математически-статистический. Результаты. Представлены результаты оптимизации питания семенных посевов клевера лугового на основе рационального применения быстродействующих известковых $\left(\mathrm{Ca}(\mathrm{OH})_{2}-0,5\right.$ нормы по гидролитической кислотности, минеральных $\left(\mathrm{N}_{30} \mathrm{P}_{60} \mathrm{~K}_{60}\right)$ и водорастворимых удобрений, что обеспечило повышение урожая семян в 1,8-2,0 раза в уровне 0,35-0,40 т/га. Выводы. Наиболее эффективным является сочетание основного удобрения минеральными $\left(\mathrm{N}_{30} \mathrm{P}_{60} \mathrm{~K}_{60}\right)$ и известковыми удобрениями $\left(\mathrm{Ca}(\mathrm{OH})_{2}\right)$ в 0,5 норме по гидролитической кислотности, внесенных под покровную культуру с применением молибденовых удобрений $\left(\left(\mathrm{CNH}_{4}\right)_{2} \mathrm{MoO}_{4}-\right.$ 0,3 кг/га) весной в начале отрастания клевера лугового, водорастворимых (Плантафол - 1,0 кг/га) и борных удобрений $\left(\mathrm{H}_{3} \mathrm{BO}_{4}-0,8\right.$ кг/га) в фазу стеблевания второго укоса.

Ключевые слова: клевер луговой, семенные посевы, урожай, известковые, минеральные и водорастворимые удобрения.

\section{REFERENCES}

1. Lopushnyak $V$, Lahush $N$. Influence of the post-effect of durable application of fertilizers in grain-cultivated crop rotation on clover productivity. Kormy $\mathrm{i}$ kormovyrobnytstvo. 2013;77:251-5. (in Ukrainian).

2. Bozhenko AI. Heterosis of F1 hybrids obtained by undercover and summer sowings and hereditary influence of summer crops on the yield properties of red clover. Kormy i kormovyrobnytstvo. 2013;76:83-8. (in Ukrainian).

3. Tsurkan NV. Condition and trends of the development of production of perennial herbages in the southern Steppe of Ukraine. Kormy i kormovyrobnytstvo. 2012;74:4852. (in Ukrainian).

4. Kvitko GP, Tkachuk OP, Hetman NY. Perennial legumes as a basis of natural intensification of feed production and improvement of soil fertility in the Forest-Steppe of Ukraine. Kormy i kormovyrobnytstvo. 2012;73:113-7. (in Ukrainian).

5. Zapruta OA, Antoniv SF, Kolisnyk SI. Scientific bases for increasing seed productivity and sowing qualities of red clover in the Forest-Steppe of Ukraine. Kormy $i$ kormovyrobnytstvo. 2017;83:38-45. (in Ukrainian).

6. Hospodarenko HM. Agrochemicals. K.: Ahrarna osvita, 2013:406 p. (in Ukrainian).

7. Poliovyi VM, Lavruk MM, Kulyk SM. Differentiation of physicochemical parameters and productivity of sodpodzolic soil owing to long application of different fertilizer systems and doze of lime. Visnyk ahrarnoi nauky. 2018;5:12-7. (in Ukrainian).

8. Zaryshniak AS, Sypko AO, Strilets OP, Zatserkovna NS, Sinchuk GA, Goncharuk HS, Hrytsyshyna LG, Kostashchuk MV, Mazur GM. Restoration and regulation of fertility of acid soils in conditions of Forest-Steppe of Ukraine. Visnyk ahrarnoi nauky. 2018;(3): 5-12. (in Ukrainian).

9. Tsapko JuL, Desiatnyk KO, Ogorodnia AI, Meshref RB. Amelioration of acid soils - alternative approaches. Visnyk ahrarnoi nauky. 2016;(1):12-5. (in Ukrainian).

10. Tkachenko M.A. Forage crops yields depending on the chemical amelioration and system of fertilization of grey forest soil. Kormy i kormovyrobnytstvo. 2014;78:94103. (in Ukrainian).

11. Zabarna TA, Zabarny AS, Polgorodnik OG, Pelekh LV. The effect of mineral fertilizers and cultivation methods on the nitrogen-fixing ability of red clover in the rightbank Forest-Steppe. Kormy i kormovyrobnytstvo. 2013; 75:35-8. (in Ukrainian). 